
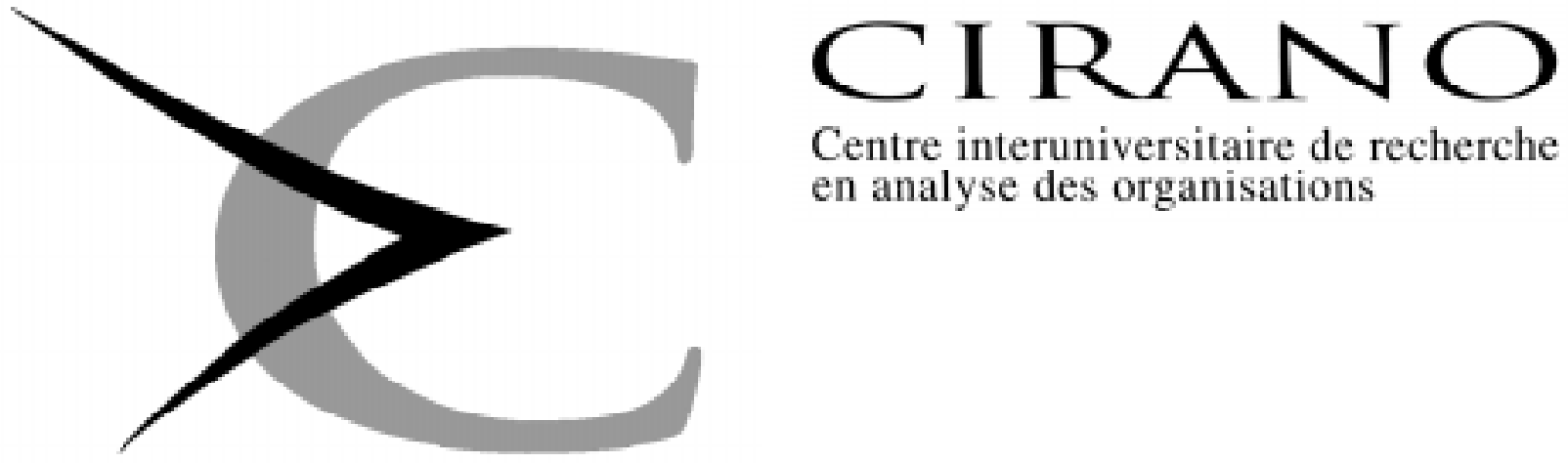

Centre interuniversitaire de recherche en analyse des organisations

Série Scientifique

Scientific Series

97s-25

Welfare Benefits, Minimum Wage

Rate and the Duration of Welfare

Spells: Evidence from a Natural

Experiment in Canada

Bernard Fortin, Guy Lacroix 


\section{CIRANO}

Le CIRANO est une corporation privée à but non lucratif constituée en vertu de la Loi des compagnies du Québec. Le financement de son infrastructure et de ses activités de recherche provient des cotisations de ses organisations-membres, d'une subvention d'infrastructure du ministère de l'Industrie, du Commerce, de la Science et de la Technologie, de même que des subventions et mandats obtenus par ses équipes de recherche. La Série Scientifique est la réalisation d'une des missions que s'est données le CIRANO, soit de développer l'analyse scientifique des organisations et des comportements stratégiques.

CIRANO is a private non-profit organization incorporated under the Québec Companies Act. Its infrastructure and research activities are funded through fees paid by member organizations, an infrastructure grant from the Ministère de l'Industrie, du Commerce, de la Science et de la Technologie, and grants and research mandates obtained by its research teams. The Scientific Series fulfils one of the missions of CIRANO: to develop the scientific analysis of organizations and strategic behaviour.

\section{Les organisations-partenaires / The Partner Organizations}

-École des Hautes Études Commerciales

-École Polytechnique

-McGill University

-Université de Montréal

-Université du Québec à Montréal

-Université Laval

-MEQ

-MICST

-Avenor

-Banque Nationale du Canada

-Bell Québec

-Caisse de dépôt et placement du Québec

-Fédération des caisses populaires Desjardins de Montréal et de l'Ouest-du-Québec -Hydro-Québec

-Raymond, Chabot, Martin, Paré

-Scetauroute

-Société d'électrolyse et de chimie Alcan Ltée

-Téléglobe Canada

-Ville de Montréal

Ce document est publié dans l'intention de rendre accessibles les résultats préliminaires de la recherche effectuée au CIRANO, afin de susciter des échanges et des suggestions. Les idées et les opinions émises sont sous l'unique responsabilité des auteurs, et ne représentent pas nécessairement les positions du CIRANO ou de ses partenaires.

This paper presents preliminary research carried out at CIRANO and aims to encourage discussion and comment. The observations and viewpoints expressed are the sole responsibility of the authors. They do not necessarily represent positions of CIRANO or its partners.

ISSN 1198-8177 


\title{
Welfare Benefits, Minimum Wage Rate and the Duration of Welfare Spells: Evidence from a Natural Experiment in Canada*
}

\author{
Bernard Fortin ${ }^{\dagger}$, Guy Lacroix
}

Résumé / Abstract

\begin{abstract}
Dans cet article, nous étudions la relation entre le niveau des prestations et la durée de séjour à la sécurité sociale. L'analyse repose sur une approche dite d'expérience naturelle et consiste à comparer la durée de séjour avant et après l'introduction de la réforme majeure qui a eu lieu en 1989 au Québec. Un volet important de cette réforme consistait à éliminer l'écart de prestations entre les individus et les couples sans enfants de moins de trente ans et les bénéficiaires âgés de plus de trente ans. Les prestations des moins de trente ans sont ainsi passées de 173 \$ par mois (\$ de 1986) à plus de 425 \$ par mois, soit une augmentation de $145 \%$. L'impact de ce changement est analysé à l'aide d'un modèle de durée semi-paramétrique qui incorpore des variables exogènes qui dépendent du temps, tels les prestations, le salaire minimum, le taux de chômage, etc. Par ailleurs, une hausse du salaire minimum a pour effet d'augmenter la durée de séjour à la sécurité sociale des individus âgés entre 18 et 24 ans, mais de diminuer la durée de séjour de ceux âgés entre 25 et 29 ans. Enfin, nos résultats montrent que la réforme a eu pour effet d'augmenter la durée de séjour d'environ 2 à 4,5 mois.

In this paper we analyze the impact of benefits on the length of welfare spells. It introduces a "natural experiment" approach of comparing the length of welfare spells before and after a major reform of the welfare program that took place in Québec in August 1989. An important feature of this reform was the abolishment of discrimination based on age that applied to single individuals and childless couples below the age of thirty. With the reform, their monthly benefits rose from $\$ 173$ (in dollars of 1986) to $\$ 425$, an increase of
\end{abstract}

\footnotetext{
" Correspondence Address: Guy Lacroix, CIRANO, 2020 University Street, 25th floor, Montréal, Qc, Canada H3A 2A5 Tel: (514) 985-4027 Fax: (514) 985-4039 e-mail: lacroixg@ cirano.umontreal.ca We would like to thank the Ministère de la sécurité du revenu for providing the data and for financial support, as well as Health and Welfare Canada and Centre québécois de la recherche sociale for financial support.

+ Université Laval, CRÉFA and CIRANO

‡ Université Laval, CRÉFA and CIRANO
} 
over $145 \%$. To analyze the impact of the reform, we utilize a semi-parametric duration model with time-varying covariates such as welfare benefits, minimum wage rate, unemployment rate, etc. We find that benefits have an important impact on spell duration of individuals below thirty years of age. We also find that the minimum wage rate has an adverse effect on the duration of individuals in the 18-24 age group but a positive effect on those in the 25-29 age group. Finally, our estimates suggest that the reform increased duration on welfare from 2 to 4.5 months.

Mots Clés : $\quad$ Prestations de sécurité sociale, salaire minimum, modèle de durée semi-paramétrique

Keywords : Welfare benefits, minimum wage, semi-parametric duration model

JEL : I30, J64 


\section{Introduction}

One of the most crucial issues concerning welfare reform is whether benefits induce "dependency" in terms of frequency and duration of participation. The existence of such dependency is likely to increase the costs of welfare programs as well as to push some welfare claimants into a poverty trap, thus encouraging the very dependency the programs seek to alleviate.

Recently, Moffitt (1992) has surveyed a growing body of literature that links welfare benefits and welfare dependency. While this literature has focused primarily on static welfare participation-that is, participation at a point in time- more recent research efforts have focused on dynamic welfare participation- that is, entry and exit into welfare. The latter studies have been mostly concerned with estimating the determinants of the exit rates (hazard rates) from AFDC rolls. Although they have generally found that the AFDC benefits levels have a negative impact on exit rates, the evidence is rather weak [e.g., O'Neill et al. (1987), Blank (1989), Ruggles (1989), Fitzgerald (1991), Giannarelli (1992), Hoynes and MaCurdy (1994)].

As suggested by Fitzgerald (1989), small (and often non-significant) estimated effects can partly be explained by data deficiencies. In most studies, the identification of the benefits effect rests essentially on crossstates variability in benefits levels and/or on within-state time variability in real benefits. One problem with cross-states variability is that differences in state benefits levels (and implicit tax rates) may be partly offset by differences in other program characteristics such as the severity in the administrative treatment of claims, the level of earnings disregard or the assets test. They may also reflect differences in state cost of living, in non-AFDC benefits or in other regional variables that are difficult to control for. Furthermore, average real monthly benefits across states have shown fairly smooth changes over time, with moderate increases between 1968 and 1974, gradual declines between 1974 and 1982 and flattening after 1982 [see Hoynes and MaCurdy (1994)]. Therefore, studies that rely on a relatively short time frame ${ }^{1}$ may lack sufficient within state variability in the benefits data, which may account for the small estimated effects. Even when the time frame is sufficiently long ${ }^{2}$, changes in real benefits are likely to be correlated with other time-evolving vari-

\footnotetext{
${ }^{1}$ For instance, Ruggles (1989), Fitzgerald (1991) and Giannarelli (1992) use the first panel of SIPP, which contains 32 months of data.

${ }^{2}$ O'Neill et al. (1987) use the NLS Young Women's panel over an 11 year period.
} 
ables that influence welfare spell duration but that are hard to measure adequately.

In Canada, only recently have studies appeared that analyze the effects of social assistance benefits on dependency. Nearly all of them [e.g., Allen (1993), Charette and Meng (1994), Dooley (1994)] are based on a static model of welfare participation and use annual survey data. They all find that the level of social assistance exerts a strong positive and significant influence on welfare participation of female heads of household. However, to our knowledge, only two papers analyze the exit rates from social assistance [Bailey (1994), Barrett (1995)]. Both are based on data from the British Columbia Income Assistance Program. Neither of them study the impact of the basic real assistance level on social assistance spell duration. ${ }^{3}$

In this paper, we analyze the impact of benefits on the length of welfare spells using information from a natural experiment that took place in the Province of Québec in August 1989. A major reform was implemented that provided for the abolishment of discrimination discrimination based on age that applied to the benefits single individuals and childless couples below the age of 30 were entitled to. ${ }^{4}$ Thus, prior to the reform, the basic benefits able-bodied singles below the age of 30 (and childless couples) were entitled to amounted approximately to $40 \%$ of those of individuals over 30 years of age. With the reform, monthly benefits were equalized and thus rose from $\$ 173(\$ 1986)$ to $\$ 425$ for those below 30 years of age, an increase of over $245 \% .^{5}$

\footnotetext{
${ }^{3}$ Bailey (1994) analyses the impact of the B.C. Enhanced Earnings Exemption and finds that its effect on exit rates is inconclusive. Barrett (1995) focuses on the shape of exit rates across various categories of households and tests for the presence of state dependency. However, he does not introduce any program parameters in his set of covariates.

${ }^{4}$ Other features of the reform were the introduction of a new, more generous, welfare program for the disabled and the replacement of the work income supplementation program (SUPRET) introduced in 1979 with a new one (APPORT), which is better integrated to the income tax system and which provides higher supplementation rates, but limited to families with children. For details, see Ministère de la Sécurité du revenu (1989). Since able-bodied single persons, who are the focus of our analysis, are not directly affected by these aspects of the reform, we will ignore them in what follows.

${ }^{5}$ In fact, in the case of single individuals, the 1989 reform introduced four basic benefits schedules depending on a claimant's situation vis-à-vis employability programs: participant, non-participant (i.e. who refuses to participate), available or not-available (due to a temporary illness, etc). Since the benefits levels vary little across these categories, and since only $10 \%$ of claimants on average participate in these programs, we did not directly take these differences into account in our analysis. However, the fixed annual effects introduced in the model may control for this
} 
Figure 1 below depicts the schedule of monthly benefits singles of both age groups were entitled to between January 1975 and December 1993. The step-wise shape arises because the benefits are generally adjusted against inflation once a year whereas we utilize the monthly CPI $(1986=100)$ to deflate them.

Figure 1

Monthly Welfare Benefit (1986\$)

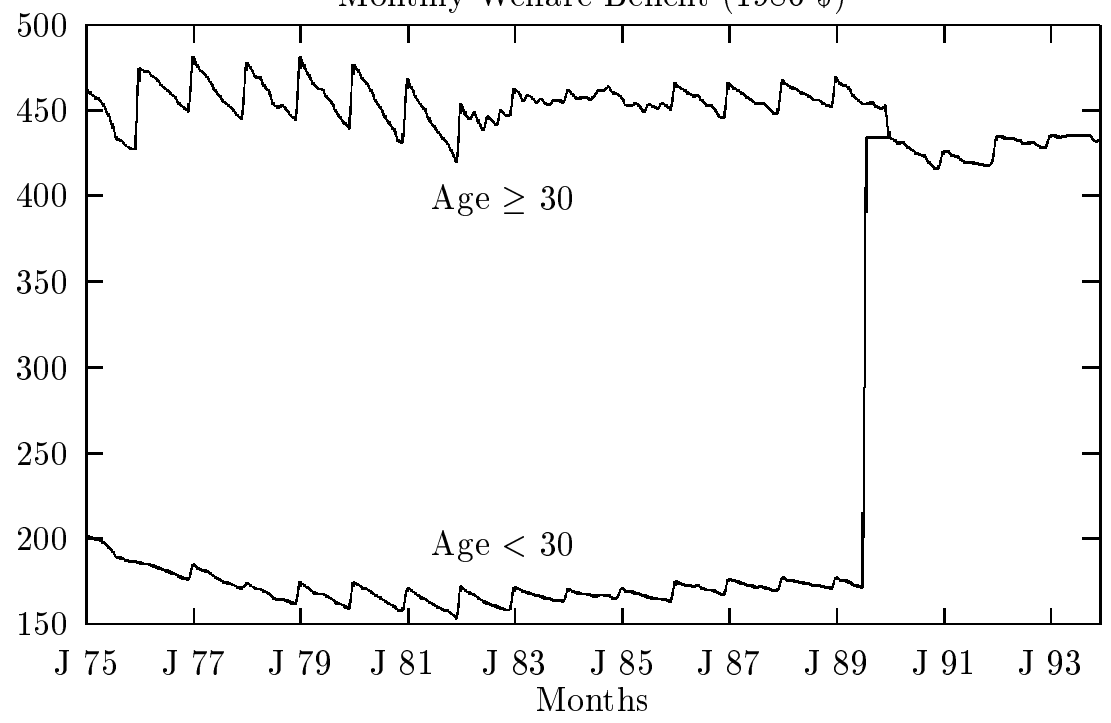

The schedule shows that the real benefits of both age groups have remained relatively constant throughout the whole period. In August 1989 (month 176), the monthly benefits are equalized at $453 \$$. The real benefits eventually decline to about $420 \$$ and remain constant thereafter. Our estimation strategy consists in exploiting the time of entry into welfare to identify the impact of benefits on duration, and the fact that only individuals below 30 years of age were subjected to such a dramatic change. As such, they constitute our "experimental group", whereas individuals over 30 years of age constitute our "control group".

To our knowledge, this paper provides the first attempt to estimate the impact of benefits levels on welfare spell duration of single individuals

feature of the reform. The schedules used in our analysis is the one that applies for those who are available for employability programs. 
since, in U.S., the AFDC programs are limited to families. The empirical analysis uses over 19 years of monthly data from the case records of the Social Assistance administrative files. The files provide accurate data on spell lengths and on many individual characteristics. Using a wide time frame allows much variation in other policy parameters such as the real minimum wage and in the overall level of economic activity. The estimation strategy recognizes that the analysis of welfare spells is sensitive to the choice of a functional form for the hazard of leaving welfare [see, e.g., Blank, (1986 and 1989)]. It thus borrows from recent work in which semi-parametric estimation techniques are used [Heckman and Singer (1984), Meyer (1990), Han and Hausman (1990)].

The paper is organized as follows. Section 2 presents a simple model of welfare spell duration consistent with a hazard framework. It highlights most features of the program parameters and potential behavioral response to these. Section 3 discusses the econometric strategy used to estimate the model. Section 4 provides a description of the data and discusses the empirical variables used in the model. Main findings are reported in section 5. Finally, we conclude the paper in section 6 .

\section{The model}

The model is assumed to be a standard discrete choice model in continuous time (e.g., Olsen, Smith and Farkas (1986)). Consider an individual on a welfare spell at period $t$. This program is defined by a guaranteed income benefit of $g_{t}$ per unit of time and a tax-back rate of $100 \%$ on his total wage earnings $\left(w_{t} h_{t}\right)$, where $w_{t}$ is the individual's wage rate at $t$ and $h_{t}$ is his hours of work at $t$, and on his private non-wage income $\left(y_{t}\right){ }^{6}{ }^{6}$ Note that $y_{t}$ includes returns from net assets. The individual also receives an exogenous benefit $a_{t}$ (e.g., a refundable sales tax credit) from other income security programs.

Under the assumption that $g_{t}>y_{t}$, the individual's non-convex budget constraint at $t$ is illustrated by BCE in Figure 2.The individual is a welfare claimant as long as his private earnings are less than the break even income $\left(g_{t}\right)$ for the program, that is $w_{t} h_{t}+y_{t}<g_{t}$. This situation corresponds to the segment BC. The slope of this segment, which reflects the individual's net wage rate, is zero since the tax-back rate on wage

\footnotetext{
${ }^{6}$ The relevant tax-back rate for singles on social assistance in Québec is $100 \%$ above a very small earnings exemption.
} 
earnings is $100 \%$. If $w_{t} h_{t}+y_{t} \geq g_{t}$, the individual is no longer eligible for welfare and his marginal wage rate is $w$ (see segment $\mathrm{CE}$ ).

\section{Figure 2}

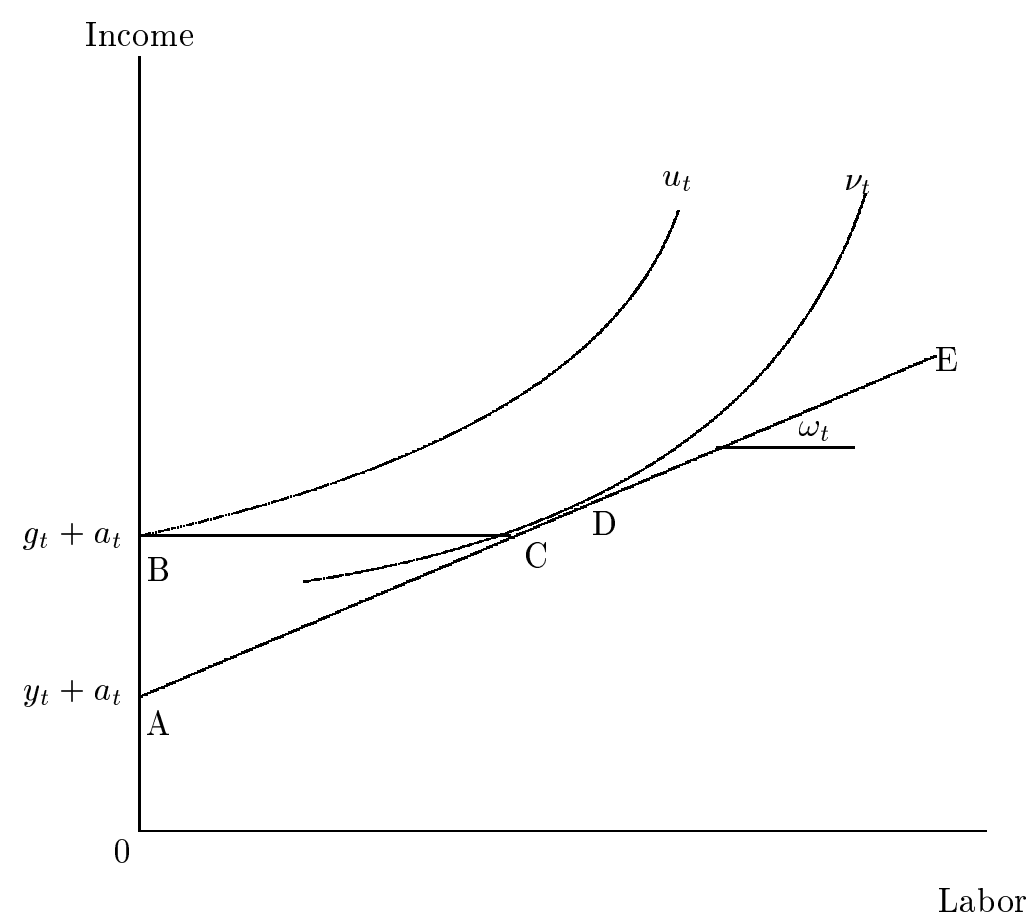

Conditional upon receiving new information at time $t$, his decision to pursue or not his spell on welfare depends on a comparison between his utility at $t$ if he enters the labour market and his utility on the welfare program. ${ }^{7}$ The formulation of the hazard associated with this model first requires the derivation of the utility attached to each alternative.

${ }^{7}$ Given the $100 \%$ tax-back rate, the individual has no incentives to work in the official market while receiving welfare benefits, i.e., he will prefer the point $\mathrm{B}$ on Figure 2 In our sample, approximately $5 \%$ of the welfare recipients report labour income. One explanation is the presence of the small earnings exemption in the welfare system. 
Under the assumption that the individual is myopic and chooses his hours of work and consumption to maximize his utility at each period $t$, his indirect utility at $t$, conditional upon his choice to enter the labour market, is an increasing function of his wage rate $w_{t}$ and of his exogenous non-welfare income, $y_{t}+a_{t}$. Note that, in our sample, the individual wage rate is unobservable. However, it is assumed to depend on a vector of individual characteristics, $s_{t}$ (e.g., education, region, sex, age), and on the current spell duration (due to the depreciation of human capital or the effect of negative signals sent to potential employers: $w_{t}=w\left(s_{t}, t\right)$ ). The latter effect can thus introduce some duration dependence into the model. The conditional indirect utility also depends on a vector of variables reflecting the economic environment, $m_{t}$, on the current duration of his spell, $t$, and on a random term $\epsilon_{t}^{l}$. The direct effect of the variable $t$ reflects the possibility that the spell length affects the individual's preferences (another reason for the presence of duration dependence). The random term $\epsilon_{t}^{L}$ reflects the arrival of new information affecting the individual's utility in the labour market. $\epsilon_{t}^{L}$ is unknown to the econometrician but is assumed to be observed by the individual before he takes his decision at $t$. Substituting the wage rate by its function $w\left(s_{t}, t\right)$ into the conditional indirect utility and assuming that $\epsilon_{t}^{L}$ enters linearly the utility function, the latter is therefore given by:

$$
\begin{gathered}
v_{t}=v\left(y_{t}+a_{t}, x_{t}, t\right)+\epsilon_{t}^{L}, \\
\text { where } x_{t}=\left(s_{t}, m_{t}\right), \\
\text { with } v_{y_{t}}>0, v_{a_{t}}>0 .
\end{gathered}
$$

Point D in Figure 2 represents the individual's choice, conditional upon entering the labour market at $t$.

On the other hand, the individual's (direct) utility function, conditional upon pursuing his spell on welfare at $t$, depends on his consumption level on welfare $\left(g_{t}+a_{t}\right)$, on his hours of work $(=0)$, on the vector $x_{t}$ of control variables, on the current spell duration $t$, and on a random term $\left(\epsilon_{t}^{W}\right)$ reflecting the arrival of information affecting (linearly) his utility on welfare. The individual's utility function on welfare is thus:

$$
\begin{gathered}
u_{t}=u\left(g_{t}+a_{t}, 0, x_{t}, t\right)+\epsilon_{t}^{W}, \\
\text { with } u_{g_{t}}>0, u_{a_{t}}>0 .
\end{gathered}
$$


Point B in Figure 2 illustrates the individual's choice at $t$, conditional upon being on welfare.

The decision process is assumed to take the following form. New values of the error terms (the $\epsilon$ 's) arrive at random intervals. When this new information arrives, the preferred alternative is chosen. ${ }^{8}$ Following Olsen, Smith and Farkas (1986), we assume that the arrival of new information follows a Poisson process with constant rate $\nu .{ }^{9}$ Assuming that the error terms are temporally independent and using eqs. (1) and (2), the instantaneous rate of exit from welfare at $t$, given that the duration has lasted until $t$, is given by:

$\lambda\left(y_{t}, a_{t}, g_{t}, x_{t}, t\right)=\nu\left[\operatorname{Prob}\left(v\left(y_{t}+a_{t}, x_{t}, t\right)+\epsilon_{t}^{L} \geq u\left(g_{t}+a_{t}, 0, x_{t}, t\right)+\epsilon_{t}^{W}\right]\right.$.

Eq. (3) yields the hazard function of the model. Define $\mu_{t}$ as $\epsilon_{t}^{W}-\epsilon_{t}^{L}$. $\mu_{t}$ is a white noise with a distribution function given by $F\left(\mu_{t}\right)$. Define also $\mu_{t}^{c}$ as the difference between the non stochastic components of the utility level on the labour market $v(\cdot)$ and on welfare $u(\cdot)$. One has: $\mu_{t}^{c}=\mu^{c}\left(y_{t}, a_{t}, g_{t}, x_{t}, t\right)$ with $\mu_{y_{t}}^{c}>0, \mu_{a_{t}}^{c}<0$ (assuming that leisure is a normal good) and $\mu_{g_{t}}^{c}<0$. Therefore, (3) becomes

$$
\begin{gathered}
\lambda\left(z_{t}, t\right)=\nu \operatorname{Prob}\left[\mu_{t} \leq \mu^{c}\left(z_{t}, t\right)\right]=\nu F\left[\mu^{c}\left(z_{t}, t\right)\right] \\
\text { where } z_{t}=\left(y_{t}, a_{t}, g_{t}, x_{t}\right) \text { and } \\
\quad \text { with } \lambda_{y_{t}}>0 ; \quad \lambda_{a_{t}}, \lambda_{g_{t}}<0 .
\end{gathered}
$$

Hence, the level of private non-wage income $\left(y_{t}\right)$ has a positive effect on the rate of exit from welfare, since it is $100 \%$ taxed on welfare while it is not taxed at all when the individual is on the labour market. Moreover an increase in the exogenous benefits from other income security programs $\left(a_{t}\right)$ reduces the exit rate from welfare as long as leisure is a normal good. Finally, an increase in the level of welfare benefits $\left(g_{t}\right)$ has also a negative effect on the hazard rate of leaving welfare.

\footnotetext{
${ }^{8}$ For simplicity, we ignore the possibility that the exogenous variables might change between successive arrivals of the $\epsilon$ 's which would result in the choice of returning to the labor market [see Heckman and Singer (1984)].

${ }^{9} \mathrm{It}$ is easy to generalize the model to the case where $\nu$ depends on a vector of exogenous variables.
} 
Our model can be generalized for more realism. First, rationing in the labour market can be simply introduced by assuming that $h_{t} \leq \bar{h}_{t}$, where $\bar{h}_{t}$ is the maximum hours that can be worked by the individual at $t$. Under the assumption that this constraint is binding, the individual's utility level, conditional upon entering the labour market, is now given by the constrained direct utility function: $v_{t}=u\left(w_{t} \bar{h}_{t}+y_{t}, \bar{h}_{t}, x_{t}, t\right)+\epsilon_{t}^{L}$. Replacing the conditional indirect utility function $v(\cdot)+\epsilon_{t}^{L}$ with this constrained direct utility function in eq. (3), it is easy to show that $\lambda_{\bar{h}_{t}}>$ 0 , that is, a decrease in labour market rationing raises the individual's rate of exit from welfare.

Second, it is likely that the generosity of the unemployment insurance (UI) program influences the exit rate from welfare. First, receiving UI benefits can make the individual ineligible for welfare, as long as his private income and UI benefits exceed the break-even income of the welfare program. Second, UI benefits can entice the individual to leave welfare and to enter the labour market, given the expectations of future UI benefits if he becomes unemployed. In the empirical section, a UI eligibility parameter, defined as the ratio between the minimum number of working weeks required to get eligible for UI and the maximum number of weeks of UI eligibility, is included as an explanatory variable. ${ }^{10}$

\section{Estimation Strategy}

The aim of this section is to discuss the approach we adopt to estimate the hazard function (4). As in Meyer (1990), the hazard is assumed to take the following form ${ }^{11}$ :

$$
\lambda\left(z_{t}, t\right)=\lambda_{0}(t) \exp \left(z_{t}^{\prime} \beta\right)
$$

where $\lambda_{0}(t)$ is the baseline hazard (i.e., the hazard when $z_{t}=0$ ) and $\beta$ is a vector of parameters to be estimated.

It has been argued that using a non parametric form in estimating the part of the hazard common to all individuals (the baseline hazard) is more adequate than imposing a parametric form for three reasons.

\footnotetext{
${ }^{10}$ There was not enough variability in the UI wage replacement ratio over the sample period to include this variable in the model.

${ }^{11}$ This approach is widely used in labor economics (e.g., Belzil (1993). It is based on the idea that individual hazard functions differ across individuals up to a proportional factor.
} 
First, specific forms of the baseline hazard (e.g., Weibull) lack theoretical support. Second, in many circumstances, the shape of the baseline hazard is irregular and unlikely to be well approximated by a simple parametric form. ${ }^{12}$. Third it can be shown that misspecification of the baseline hazard yields inconsistent estimate of $\beta$.

For empirical purposes, it may be useful to generalize equation (5) to consider unobserved heterogeneity between individuals. It is well know that if unaccounted for, the overall hazard can exhibit spurious negative duration dependence. Therefore, equation (5) can be rewritten to account for $\theta$, a random variable reflecting the individual's unobserved characteristics. Assuming that heterogeneity takes a multiplicative form, the resulting mixed proportional hazard model is given by:

$$
\lambda\left(z_{t}, t ; \theta\right)=\theta \exp \left(z_{t}^{\prime} \beta\right) \lambda_{0}(t)
$$

A convenient and commonly used distribution for $\theta$ is the gamma distribution ${ }^{13}$ with mean normalized to one and variance $\sigma^{2}$. Under this assumption and given observations of failure times over the discrete periods $t=t_{0}, t_{1}, t_{2}, \ldots, t_{T-1}$ for individuals $i=1, \ldots, N$, Meyer (1986) has shown that the resulting log-likelihood is given by:

$$
\begin{aligned}
L\left(\gamma, \beta, \sigma^{2}\right)= & \sum_{i=1}^{N} \log \left\{\left[1+\sigma^{2} \cdot \sum_{j=0}^{k_{i}-1} \exp \left\{\gamma_{t_{j}}+z_{i t_{j}}^{\prime} \beta\right\}\right]^{-\sigma^{-2}}\right. \\
& \left.-\delta_{i}\left[1+\sigma^{2} \cdot \sum_{j=0}^{k_{i}} \exp \left\{\gamma_{t_{j}}+z_{i t_{j}}^{\prime} \beta\right\}\right]^{-\sigma^{-2}}\right\}
\end{aligned}
$$

where $\gamma_{t_{j}}=\ln \left(\int_{t_{j}}^{t_{j+1}} \lambda_{0}(v) d v\right), \quad \gamma=\left[\gamma_{t_{0}}, \gamma_{t_{1}}, \ldots, \gamma_{t_{T-1}}\right], z_{i t_{j}}$ is a vector of time dependent explanatory variables for individual $i, \delta_{i}=1$ if the duration for individual $i$ is not (right) censored, $=0$ otherwise and $t_{k_{i}}$ is the observed (censored or not) duration of individual $i$ 's spell on SA.

\footnotetext{
${ }^{12}$ For instance, Meyer (1990) mentions that U.S. studies of unemployment durations have found irregular spikes in the hazard at about 24 and 36 weeks.

${ }^{13}$ Other distributions could be used; in particular, the heterogeneity distribution could be non-parametric. However, as conjectured by Meyer (1990), if the baseline hazard takes a flexible form, the choice of the heterogeneity distribution may be unimportant.
} 
This specification has been used by many authors recently to study unemployment spells, job tenure, etc. Dolton and van der Klaauw (1995), Arulampalam and Stewart (1995), Anderson (1992)].

\section{Data}

The basic sample we use is taken from the monthly case records of the social assistance program in the Province of Québec. The administrative files contain detailed information on individual characteristics. It is thus possible to identify those who are permanently handicapped or seriously ill. These individuals are excluded from the sample to avoid sampling individuals whose risk of exit is practically zero. The sample consists of 95514 healthy or lightly impaired individuals drawn randomly from the population with a social assistance (SA) history between January 1979 and December 1993. The drawing is performed on the basis of the social insurance number and is thus not related to the frequency or the length of individual episodes. In all, these 95514 individuals experimented 180 659 spells of welfare over the sample period, or 1.89 spell on average per individual.

To avoid left censoring, individuals who were in the midst of a spell in January 1979 were followed back as early as January 1975. Spells that were uninterrupted between January 1975 and January 1979 were considered left censored and removed from the sample. Hence, spells may have started as early as February 1975 and as late as December 1993. Such a wide window allows considerable variation in program parameters and labor market conditions, a necessary condition to identify the contribution of each to exit probabilities. A spell of SA is defined as a sequence of consecutive months of SA receipt. An exit occurs when an individual is one month not in receipt of SA benefits. Right censoring occurs if a spell was ongoing in December 1993.

\subsection{Descriptive statistics}

Single individuals, which are the focus of this paper, constitute the largest group of welfare claimants. They represent approximately $60 \%$ of all household in our sample and $48 \%$ of total spells. As Many as 4 732 individuals got married or had a child following entry into welfare. Spells during which the "single" status changed were removed from the 
analysis. $^{14}$ As well, age (in month) at the start of the spell determines the age group to which the individual belongs.

Prima facie evidence on the impact of the 1989 reform is provided by an examination of the empirical exit rates before and after its implementation. Figures $3 \mathrm{a}-3 \mathrm{f}^{15}$ plots Kaplan-Meier estimates of exit rates for men and women separately and for three different age groups over a period of 5 years. For each age group the figure plots the exit rates for all the episodes that occurred before 1989 and for those that occurred in 1989 or after. ${ }^{16}$ The exit rates are computed over 6 month intervals. Recall that only individuals below the age of 30 have been affected by the reform. Figure $3 \mathrm{a}-3 \mathrm{c}$ clearly show that the exit rates of women in the 18-24 and 25-29 age groups have decreased significantly after 1989. In the first semester following the reform, the exit rates declined from $37.6 \%$ to $29.2 \%$ and from $33.6 \%$ to $30.6 \%$, respectively. On the other hand, women in the 30-45 age group show no decrease in exit rates. If anything, exit rates increase slightly after 1989 .

Figures 3d-3f plot men's exit rates. In general, the decline in exit rates following the reform is more pronounced for men. For those in the 18-24 age group, the exit rate for the first 6 months decreased from $45.6 \%$ to $33.8 \%$. It decreased almost as much for men in the 25-29 age group $(43.8 \% \rightarrow 35.3 \%)$. Notice that the exit rates decreased slightly for men in the 30-45 age group in the first 2 semesters but show little difference thereafter.

Naturally, the decrease in exit rates after 1989 can not be attributed to the reform alone. The deteriorating labour market that accompanied the economic downturn of 1991 may have hurt younger individuals more. The unemployment rate rose steadily between January 1990 December 1993. It is quite likely that the incidence of unemployment is not distributed uniformly across age groups or gender. Finally, while benefits more than doubled in 1989, the minimum wage was at its lowest level over the past 20 years. Indeed, the nominal minimum wage remained constant from October 1981 until September 1986. Figure 4 below depicts the monthly real minimum wage rate from January 1975 to December 1993.

\footnotetext{
${ }^{14}$ We also treated these spells as censored and included them in the analysis. The econometric results were robust to their inclusion.

${ }^{15}$ In appendix.

${ }^{16}$ Episodes that started before 1989 and are still ongoing in 1989 are treated as censored.
} 
Figure 4

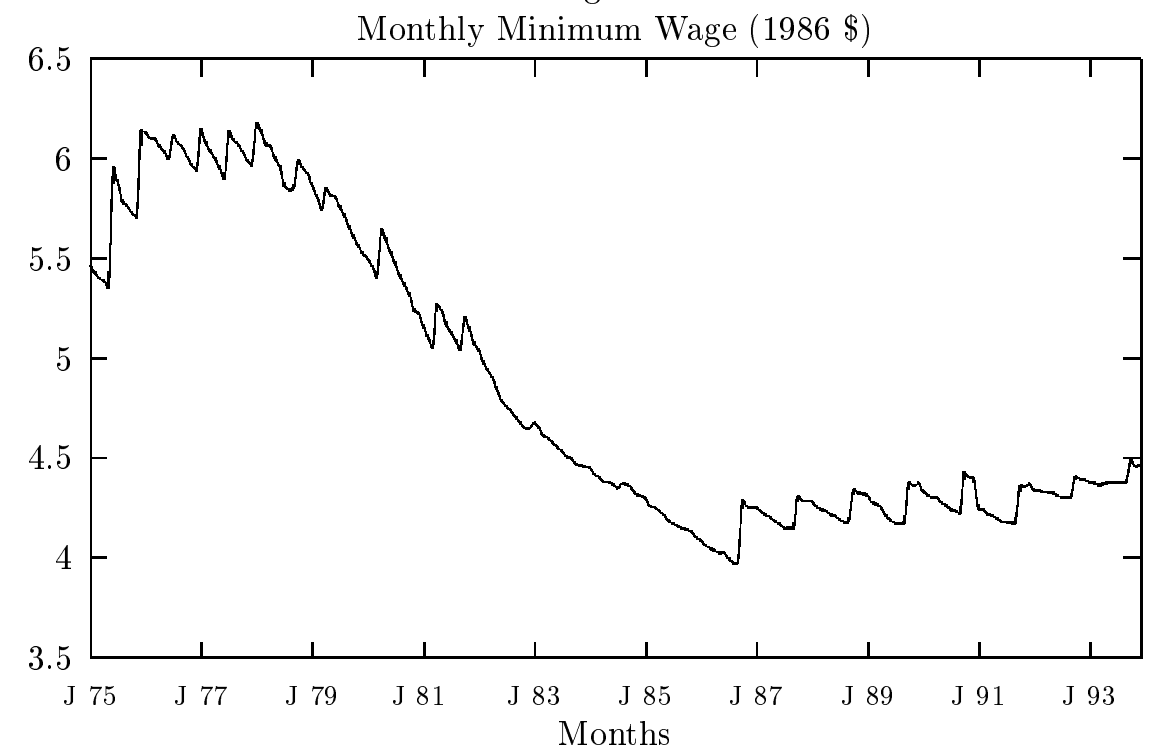

The figure clearly shows that the minimum wage rate decreased markedly between April 1978 (month 40) and August 1985 (month 140). Over the whole period the average minimum wage rate was approximately $\$ 4.84$ $(1986 \$)$. It peaked at $\$ 6.00$ between in $1976-1977$, and bottomed at $\$$ 3.97 in August 1985.

Rising unemployment rates, increased benefits and low minimum wage rates can all be conducive to lower exit rates. Other factors may also be responsible for the sharp decline in exit rates in the post-1989 period. Indeed only $30 \%$ of the total caseload were able-bodied individuals in 1975 and this proportion was $81 \%$ in 1993 . The characteristics of able-bodied individuals have remained relatively constant until 1989. In the following years, the average level of education of male beneficiaries under 30 years of age decreased nearly 1 year while that of women remained remarkably constant. The proportion of individuals born outside Canada rose from $1 \%$ to nearly $10 \%$ during the same period. Finally, the proportion of individuals living in the City of Montreal also increased considerably. This is partly due to the fact that the majority of beneficiaries born outside Canada who elect to migrate to Québec tend to locate in Montreal.

Table 1 presents sample descriptive statistics. As shown, women of all age groups experience on average longer spells than men of the same 
group. The mean duration of spells also increases with age. Men and women between 18 and 24 years of age account for more than $52 \%$ of all beneficiaries in the sample period but experience relatively short spells.

The next panel presents descriptive statistics on variables that are constant throughout spells. ${ }^{17}$ The individuals in our sample are generally poorly educated. The average schooling is somewhat less than highschool (12 years in Québec). This is true of all age groups. Note that women are on average slightly better educated than men, which is also true of the total population in general. Finally, the table indicates the proportion of individuals living in the City of Montreal (excluding its suburbs). The city represents approximately $15 \%$ of the total provincial population. Beneficiaries over 25 years of age are overrepresented in Montreal. This probably reflects the fact the Montreal has the lowest per capita income of all large cities in Canada.

The last panel concerns variables which vary over spells. Unlike education, the average age at the start of a spell is remarkably constant through time for all groups, even following the reform of 1989. The monthly welfare benefits are computed from program parameters. The large standard error for individuals under 30 years of age is primarily due to the reform of 1989. Note that in real terms, the benefits of individuals over 30 years of age vary little. The monthly unemployment rate of adult men was chosen over other definitions since it probably best represents the true labor market tightness of strongly attached individuals. Much of the variation in the minimum wage is due to the fact that it remained constant in nominal terms for nearly 5 years at a time when inflation varied considerably. Finally, the eligibility conditions (generosity variable) of the unemployment insurance program is measured as the ratio between the number of weeks of entitlement and the minimal number of weeks of work necessary to get eligible for benefits. These two parameters depend on the regional unemployment rates. To avoid simultaneity bias, the generosity is computed at the overall mean unemployment rate over the sample period for each region separately.

\section{Results}

In order to implement the approach described in section 3, ongoing lengthy spells must be censored. Given that our data span over 19 years

\footnotetext{
${ }^{17}$ Note that few individuals move between regions. For those who do, the region where they spent most time during their spell is retained as region of residence.
} 
of monthly SA receipt, we censor all observations lasting more than 40 months. For the samples of men, spells lasting more than 40 months account for between $.8 \%$ and $4.1 \%$ of total spells, while for women they account for $2.3 \%$ to $14.3 \%$ of all spells. Despite the large sample sizes, some spell lengths have few observations. Furthermore, to keep the number of estimated parameters within reasonable range, it was decided to split the spell lengths within 21 intervals. Each interval corresponds to a given element of $\gamma$. These intervals are (months): 1, 2, 3, 4, 5, 6, 7, 8, $9,10,11,12,13,14,15-16,17-18,19-21,22-25,26-31,32-39,40+$

The time-varying variables must be computed for each interval following the month of entry into the social assistance program. For intervals that last more than one month, the variables are averaged out over the interval. Hence, benefits, minimum wage, unemployment rate and UI generosity variables are computed in this fashion. Individuals who turn 30 in the midst of a spell are imputed the appropriate benefit. If this happens in an interval that is greater than one month, they are imputed a weighted average of benefits for that interval. Finally, we created 3 vectors of dummy variables to control for potential seasonnality in the exit rates. Each vector consists of a sequence of 1's and 0's where the 1 's represent the months of the relevant quarter. The omitted quarter is January-March. Finally, note that we did not include the private nonwage income variable (the variable $y$ in the theoretical model), since the level of assets is likely to be an endogenous variable while our estimating model is a reduced-form one. Moreover, we could not estimate the impact of the non-welfare benefits (the variable $a_{t}$ ) due to lack of variability in this variable over the sample period.

The estimation results for women and men are reported in Tables 2 and 3 , respectively. ${ }^{18}$ Separate estimations were conducted for the three age groups since it is usually believed that the behavioral response to program and policy parameters varies with age.

\footnotetext{
${ }^{18}$ We managed to estimate the model with unobserved heterogeneity only with sample of men between 25 and 29 years of age. Other samples always converged to $\sigma^{2}=0$. This problem has been encountered in many studies that used the same econometric specification [Han and Hausman (1990), Anderson (1992), Arulampalam and Stewart (1995), Meyer (1990)]. Furthermore, Monte Carlo experiments by Ridder and Verbakel (1983) have shown that a zero estimated variance is frequently found, even when the estimated and the true models are identical! Our estimations with heterogeneity always converged to the same values as those without heterogeneity. Note there exists ample evidence that omission or misspecification of the unobserved heterogeneity distribution has almost no consequences on the estimated covariates parameters in the case of a flexible baseline specification (see e.g., Dolton and van der Klaauw (1995) and Meyer (1990)).
} 
Results for the samples of women

Table 2 shows that an additional year of education has a significant impact on exit rates of the three age groups. It also shows that the impact decreases rapidly with age. Hence, an additional year of education decreases the exit rates of women in the 18-24 years group by as much as $18 \%$, but only by $1.5 \%$ for women in the $30-45$ years group. Being native from Canada increases the exit rate of women in the 25-29 years group by $12 \%$. Age has a negative and statistically significant impact on the exit rates of all women. In particular, younger women's exit rate decreases very rapidly with age. Note that age is measured in months. Thus, aging an additional year translates into a $25 \%$ decrease in exit rate in their case. For other women, an additional year translates into a $5.3 \%$ and $6.9 \%$ decrease, respectively.

The next three lines concern the seasonnality effects. The parameter estimates clearly indicate that the exit rates from welfare are highly seasonal. Not surprisingly, the quarter ranging from July to September witnesses the highest exit rates. For younger women, the exit rates increases by as much as $42 \%$ in that quarter.

Finally, the last part of the upper panel concerns policy variables. Welfare benefits, not surprisingly, have a negative impact on the exit rates but are only statistically significant for younger women. Interestingly, the minimum wage has a differentiated effect on each group. Younger women, on one hand, are adversely affected by increases in the minimum wage. On the other hand, women in the 25-29 years group are positively affected by increases in the minimum wage. Presumably, employers faced with an increased minimum wage prefer older workers. Finally, women in the 30-45 years group are not affected by changes in the minimum wage.

The unemployment rate has a strong negative effect on the hazard rate of women below the age of 30 . In a static framework, increasing unemployment can be interpreted as labour market rationing, i.e. individuals may be constrained to work less hours of work than desired (part-time instead of full-time). ${ }^{19}$ As was shown in section 2, increased rationing leads to a lower exit rate. The parameter estimate associated with the unemployment rate is consistent with both these interpretations. Finally, the generosity of the UI program has a negative and

\footnotetext{
${ }^{19}$ In a search framework, increasing unemployment is akin to a lower rate of job offers arrival. Hence, the probability of receiving an "acceptable" offer decreases, thereby lowering the exit rate.
} 
statistically significant impact on the exit rate of older women. This result is rather surprising. It may be that increases in the generosity of the UI program attracts individuals with a low labour market attachment into work (married women in the 30-45 age group). Welfare beneficiaries may thus have to compete with these new workers for work.

The lower panel of the table displays the estimated average monthly baseline exit rates along with their asymptotic standard errors. It can be shown from our econometric specification that the probability of leaving SA at time $T+1$ given an individual with mean characteristics $\bar{z}_{t}$ was on SA at time $T$ is $\operatorname{Prob}\left[T_{i} \leq \tau+1 \mid T_{i} \geq \tau\right]=1-\exp \left[-\exp \left(\bar{z}_{t}^{\prime} \hat{\beta}+\gamma_{t_{j}}-\right.\right.$ $\left.\left.\log \left(t_{j+1}-t_{j}\right)\right)\right]$. The first expression between parentheses is the sample average of all exogenous variables (time-varying and non time-varying), and the last expression simply accounts for the fact that intervals are not all of the same length. From inspection of the table it is readily seen that women from the three age groups exhibit different patterns of exit rates. In three groups, the hazard rates are increasing in the first few months. Women in the 18-24 and 30-45 age groups have very constant exit rates thereafter. Women in the $25-29$ age group display some duration dependence as their exit rates decrease rapidly after the first $5-6$ months on welfare.

\section{Results for the samples of men}

Qualitatively, the results for men are very similar to those of women. For instance, an additional year of education has a positive impact on the exit rate, but to a lesser extent than for women. On the other hand, aging an additional year has less impact on the exit rates of men $(11.6 \%$ for the youngest and $7.32 \%$ for the oldest). As for women, most regional dummy variables are negative for those in the 18-24 years group and are mostly positive for those in the 30-45 years group. Exit rates of men are also characterised by seasonal effects but on the whole, they exhibit greater seasonnality than those of women.

Welfare benefits have a negative impact on men in the 18-24 and 2529 age groups. As for women, the minimum wage has a differentiated impact across age groups. The younger men are adversely affected by an increase in the minimum wage whereas older men are positively affected. The unemployment rate has a negative impact on all age groups but in particular for those aged between 25 and 29. Finally, the generosity of the UI system has a negative impact on the exit rates of younger men, which is a rather surprising result. 
Finally, inspection of the lower panel reveals that the men of the three age groups do not display much duration dependence. Only those in the 25-29 age group have show a decrease in the exit rates following approximately a year on welfare. ${ }^{20}$

\section{Elasticities of expected duration}

The estimated baseline exit rates can be converted into expected duration [see Katz and Meyer (1990) for details]. Elasticities of expected duration can be estimated by increasing marginally any exogenous variable and computing the ratio of the percent change in expected duration and in the exogenous variable. Table 4 reports such elasticities with respect to a number of exogenous variables for each group along with their standard error. ${ }^{21}$ First, the estimated elasticity of the expected duration with respect to the benefits level is around 0.20 for both men and women of the 18-24 age group. Given that their mean duration is 11.38 and 13.23, respectively, the reform of 1989 is estimated to have increased their mean duration by 2.27 and 2.34 months, respectively. ${ }^{22}$ The only other statistically significant elasticity is that of men between 25 and 29 years of age. Given that their mean duration is approximately 16.9 months, the reform is estimated to have increased their mean duration by 4.7 months.

The next column reports the elasticities with respect to the minimum wage. As shown, a $1 \%$ increase in the minimum wage increases significantly the duration of spells of men and women in the 18-24 age group, but also significantly reduces the duration of those in the $25-29$ age group. Interestingly, men and women in the last age group are not affected by changes in the minimum wage. Our estimates thus suggests that only the very young are affected by a change in the minimum wage and that its impact differs considerably across age. The next column pertains to the unemployment rate. Not surprisingly, any increase in the unemployment rate adversely affects duration, but men of all age groups are affected whereas only women below 25 years are. This suggests that older women are less constrained into welfare that younger

\footnotetext{
${ }^{20}$ The computation of exit rates of men in the 25-29 age group account for the unobserved heterogeneity. Since the variance of the Gamma distribution is very small, there are practically no differences with exit rates computed from a specification that does not account for unobserved heterogeneity.

${ }^{21}$ The standard errors are computed numerically using the Delta method.

${ }^{22}$ This is a rough approximation. It is computed as $E(t) \times \eta \times(\log (425)-\log (172))$, where the figures in parentheses are the monthly benefits after and before the reform of August 1989.
} 
women.

Finally, the last column reports the elasticities with respect to schooling. As shown, an additional year of schooling considerably reduces mean duration. The sensitivity of duration decreases with age and is systematically greater for women. This results provides support for the widespread idea in Québec that school attendance among the youths should be mandatory to qualify for benefits.

\section{Conclusion}

In this paper the distribution of social assistance (SA) spells duration in Québec was described and analyzed. Using a sample of case records over the period 1979-1993, we focused on single individuals since they constitute by far the largest group of SA claimants and because they have been the object of a major reform that more than doubled their benefits in August 1989. To our knowledge, this is the first paper that addresses the issue of duration dependence on welfare using such large and detailed data. Previous papers dealt mainly with annual data or monthly data collected over a narrow period.

The theoretical model that we developed allowed us to sign most of the variables that enter the determination of exit rates out of SA. The econometric framework we used is flexible in the sense that it does not impose any particular constraint on the baseline hazard rate. In the empirical analysis, we introduced a number of covariates to capture some features of the UI program as well as a number of policy variables such as minimum wage and benefits level.

According to the parameter estimates, the major reform that was enacted in 1989 resulted in increasing mean spell duration between 25 months. There also appear to be little duration dependence in the date: most exit rate profiles are relatively flat even for long durations. Furthermore, our results show that the minimum wage has a negative impact on the exit rates of the youngest but a positive one on individuals between 25-29 years of age. Finally, our results strongly indicate that increased education can have a dramatic impact on mean duration into welfare. 


\section{References}

[1] Allen, D.W . (1994) "Welfare and the Family: The Canadian Experience", Journal of Labor Economics 12, S201-S221.

[2] Anderson, P.A. (1992) "Time-Varying Effects of Recall Expectation, a Reemployment Bonus, and Job Couseling on Unemployment Durations", Journal of Labor Economics 10, 99-115.

[3] Arulampalam, W. and M.B. Stewart (1995) "The Determinants of Individual Unemployment Durations in an Era of High Unemployment", Economic Journal 105, 321-332.

[4] Bailey, N. (1994) "The Effects of the B.C. Enhanced Earnings Exemptions on the Probability of Leaving Social Assistance", mimeo, University of British Columbia.

[5] Baker, M. and S.A. Rea (1994) "Unemployment Spells and Unemployment Insurance Eligibility Requirements", mimeo, University of Toronto.

[6] Bane Mary J. and D.T. Ellwood (1983) "The Dynamics of Dependence: The Routes to Self-Sufficiency", Report prepared for the U.S. Department of Health and Human Services by Urban Systems Research and Engineering, Inc., Harvard University.

[7] Barrett, G. (1995) "The Duration of Income Assistance Spells in British Columbia", mimeo, University of British Columbia.

[8] Belzil, C. (1993) "An Empirical Model of Job-to-job Transition with Self-selectivity", Canadian Journal of Economics 26, 536-551.

[9] Blank, R.M. (1986) "How Important is Welfare Dependence", NBER Working Paper 2026.

[10] _ (1989) "Analyzing the length of Welfare Spells", Journal of Public Economics 39, 245-273.

[11] Charette, M.F. and R. Meng (1994) "The Determinants of Welfare Participation of Female Heads of Household in Canada", Canadian Journal of Economics 27, 290-306.

[12] Cox, D.R. (1972) "Regression Models and Life-Tables", Journal of the Royal Statistical Society 34, 187-202.

[13] — (1975) "Partial Likelihood", Biometrika 62, 269-276. 
[14] Dolton, P. and W. van der Klaauw (1995) "Leaving Teaching in the U.K.: A Duration Analysis", Economic Journal 105, 431-444.

[15] Dooley, M. (1994) "The Use of Social Assistance Income by Canadian Lone Mothers", mimeo, McMaster University.

[16] Fitzgerald, J. (1989) "The Effects of the Marriage Market and AFDC Benefits on Exit Rates from AFDC", Institute for Research Poverty Discussion Paper 878-89.

[17] Fitzgerald, J. (1991) "Welfare Duration and the Marriage Market: Evidence from the Survey of Income and Program Participation" Journal of Human Resources 26, S45-S61.

[18] Fortin, B. and G. Lacroix (1996)"Welfare Benefits Minimum Wage Rate and the Duration of Welfare Spells: Evidence from a Natural Experiment in Canada", mimeo, CRÉFA, Université Laval.

[19] Fortin, B., M. Truchon and L. Beauséjour (1993) "On Reforming the Welfare System: Workfare Meets the Negative Income Tax", Journal of Public Economics 51, 119-151.

[20] Giannarelli, L. (1992) "AFDC Turnover and Spell Duration in the 1984 Panel of SIPP, and the Implications of those Data for the TRIM2 Model", Urban Institute Report Submitted to the Congressional Budget Office.

[21] Ham, J.C. and S.A. Rea (1987) "Unemployment Insurance and Male Unemployment Duration in Canada", Journal of Labor Economics $\mathbf{5}, 325-353$.

[22] Han, A. and J.A. Hausman (1990) "Flexible Parametric Estimation of Duration and Competing Risks Models", Journal of Applied Econometrics 5, 1-28.

[23] Hanoch, G. and M. Honig (1978) "The Labor Supply Under Income Maintenance Programs", Journal of Public Economics 9, 119-165.

[24] Heckman, J. and G.E. Borjas (1980) "Does Unemplyment Cause Future Unemployment? Definitions, Questions and Answers from a Continuous Time Model of Heterogeneity and State Dependence", Economica 47, 247-283.

[25] Heckman, J. and B. Singer (1984) "A Method for Minimizing the Distributional Assumptions in Econometric Models for Duration Data", Econometrica 52, 271-320. 
[26] Hoynes, H. and T. MaCurdy (1994) "Has the Decline in Benefits Shortened Welfare Spells?", American Economic Review, Papers and Proceedings 84, 43-48.

[27] Kaplan, E. and P. Meier (1958) "Nonparametric Estimation from Incomplete Observations", Journal of the American Statistical Association 53, 457-481.

[28] Katz, L.F. and B.D. Meyer (1990) "The Impact of the Potential Duration of Unemployment Benefits on the Duration of Unemployment" Journal of Public Economics 41, 45-72.

[29] Kiefer, N.M. (1988) "Economic Duration Data and Hazard Functions", Journal of Economic Literature 26, 646-679.

[30] Lancaster, T. (1979) "Econometric Methods for the Duration of Unemployment", Econometrice 47, 939-956.

[31] Meyer, B.D. (1986) "Semiparametric Estimation of Hazard Models", mimeo, MIT.

[32] Meyer, B.D. (1990) "On Unemployment Insurance and Unemployment Spells", Econometrica 58, 757-782.

[33] Moffitt, R. (1983) "An Economic Model of Welfare Stigma", American Economic Review 73, 1023-1035.

[34] Moffitt, R. (1992) "Incentive Effects of the U.S. Welfare System: A Review" Journal of Economic Literature 30, 1-61.

[35] Nickell, S. (1979) "Estimating the Probability of Leaving Unemployment", Econometrica 47, 1249-1266.

[36] Olsen, R.J., A. Smith and G. Farkas (1986) "Structural and Reduced-Form Models of Choice among Alternatives in Continuous Time: Youth Employment Under a Garanteed Jobs Program" Econometrica 54, 375-394.

[37] O'Neill, J., D.A. Wolf, L.J. Bassi and M.T. Hannan (1987) "The Duration of Welfare Spells", The Review of Economics and Statistics 69, 241-248.

[38] Prentice, R. and L. Gloeckler (1978) "Regression Analysis of Grouped Survival Data with Aplication to Breast Cancer Data", Biometrics 34, 57-67. 
[39] Ridder, G. and W. Verbakel (1983) "On the Estimation of the Proportional Hazard Model in the Presence of Unobserved Heterogeneity", mimeo, University of Amsterdam.

[40] Ruggles, P. (1989) "Welfare Dependency and its Causes: The Determinants of the Duration of Welfare Spells", Bureau of the Census SIPP Working Paper Series 8908. 
Figure 3a

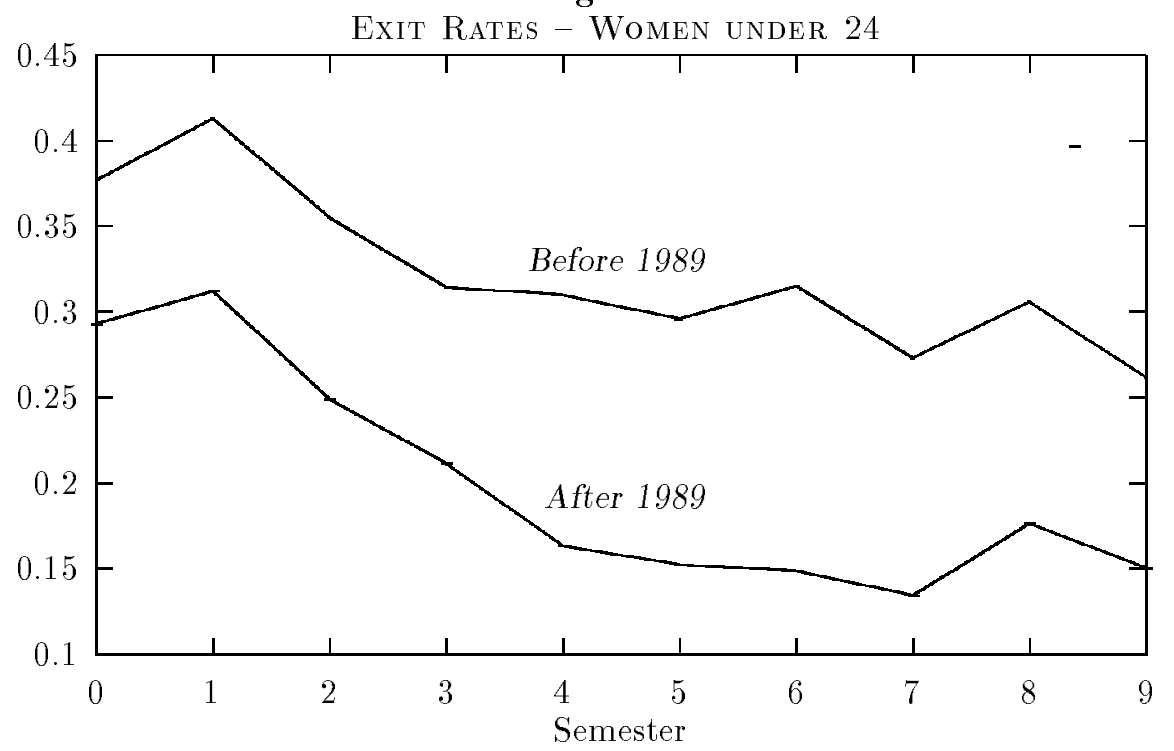


Figure 3b

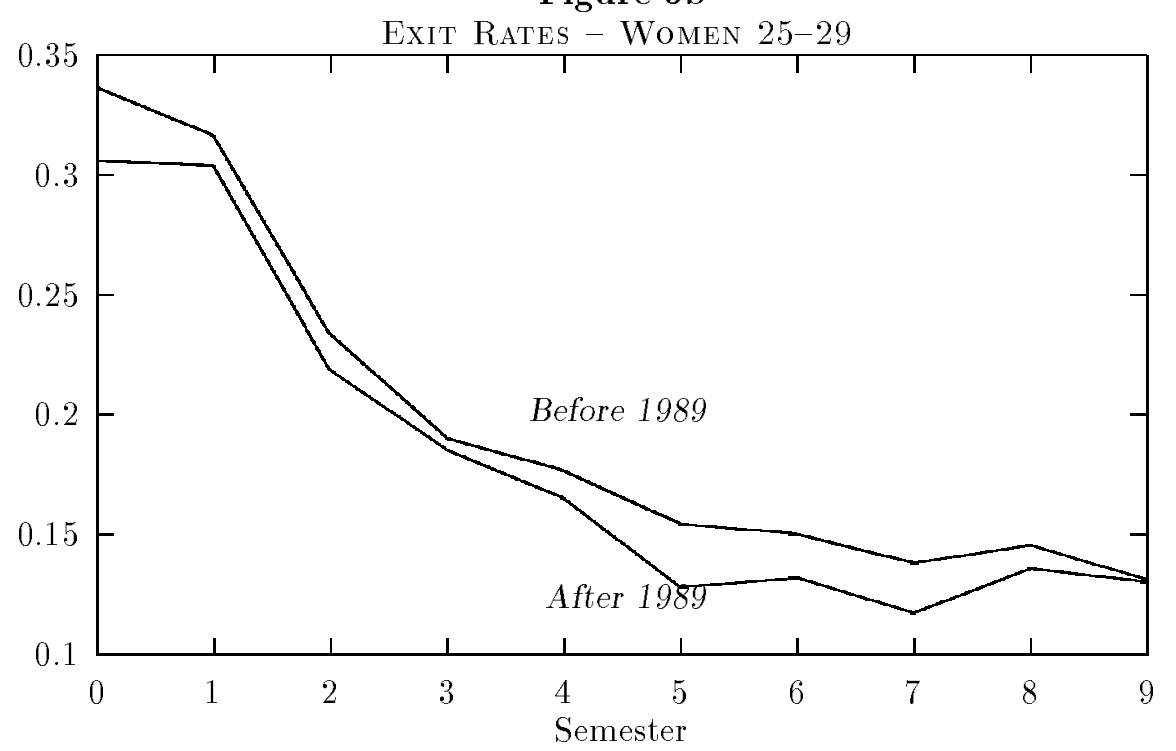


Figure 3c

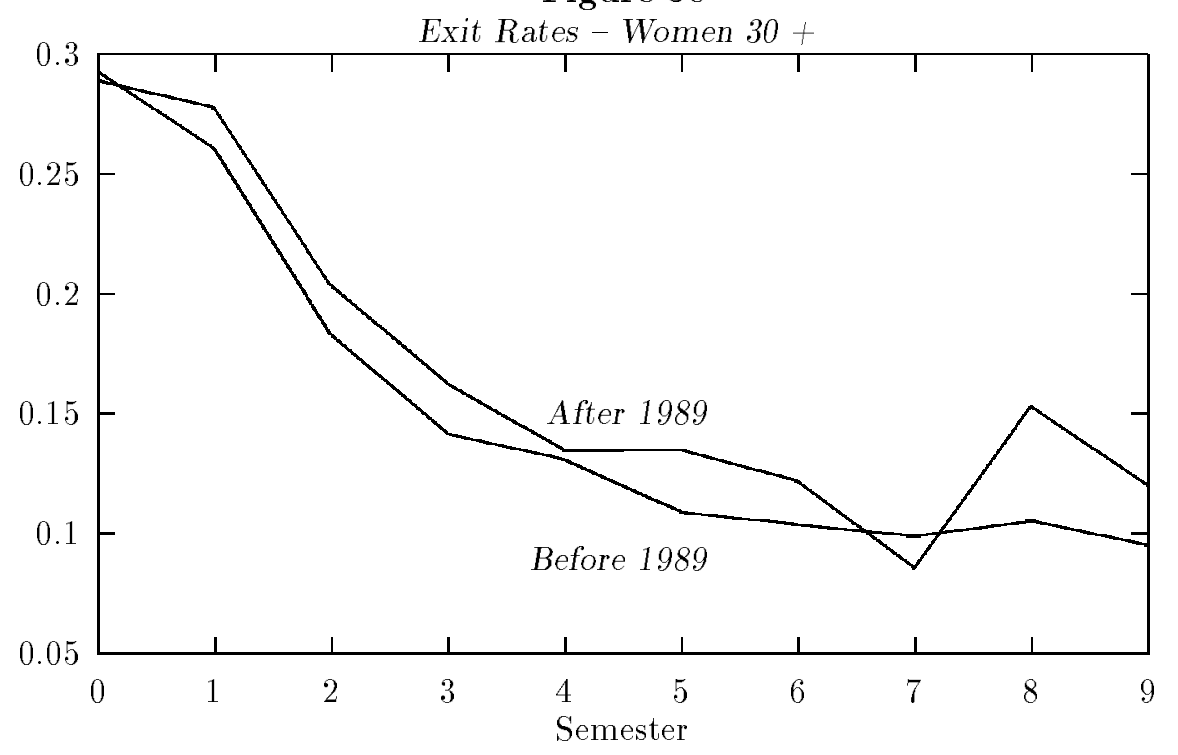


Figure 3d

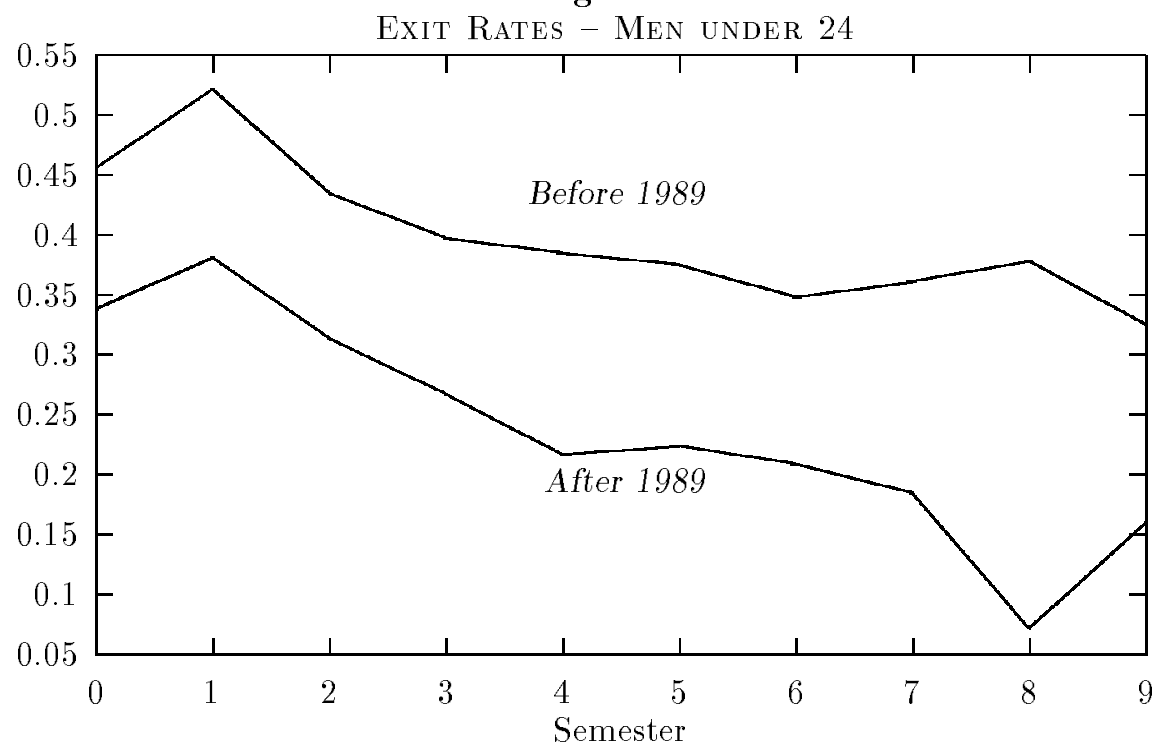


Figure 3e

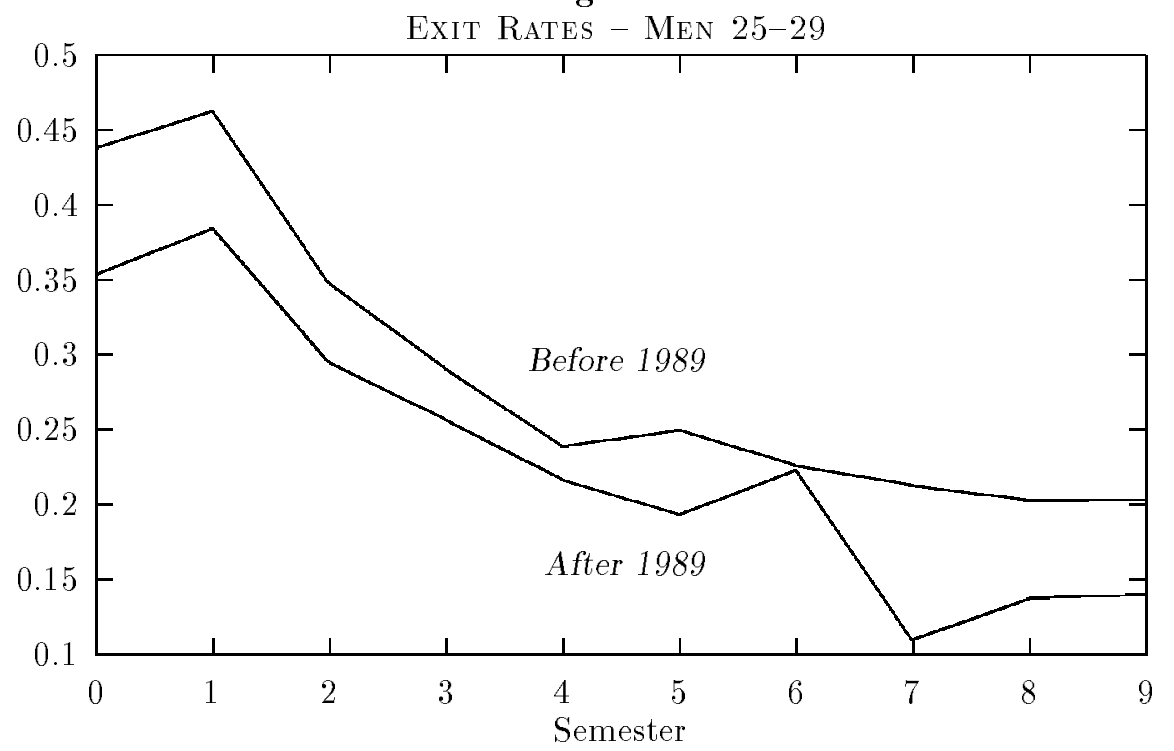


Figure $3 f$

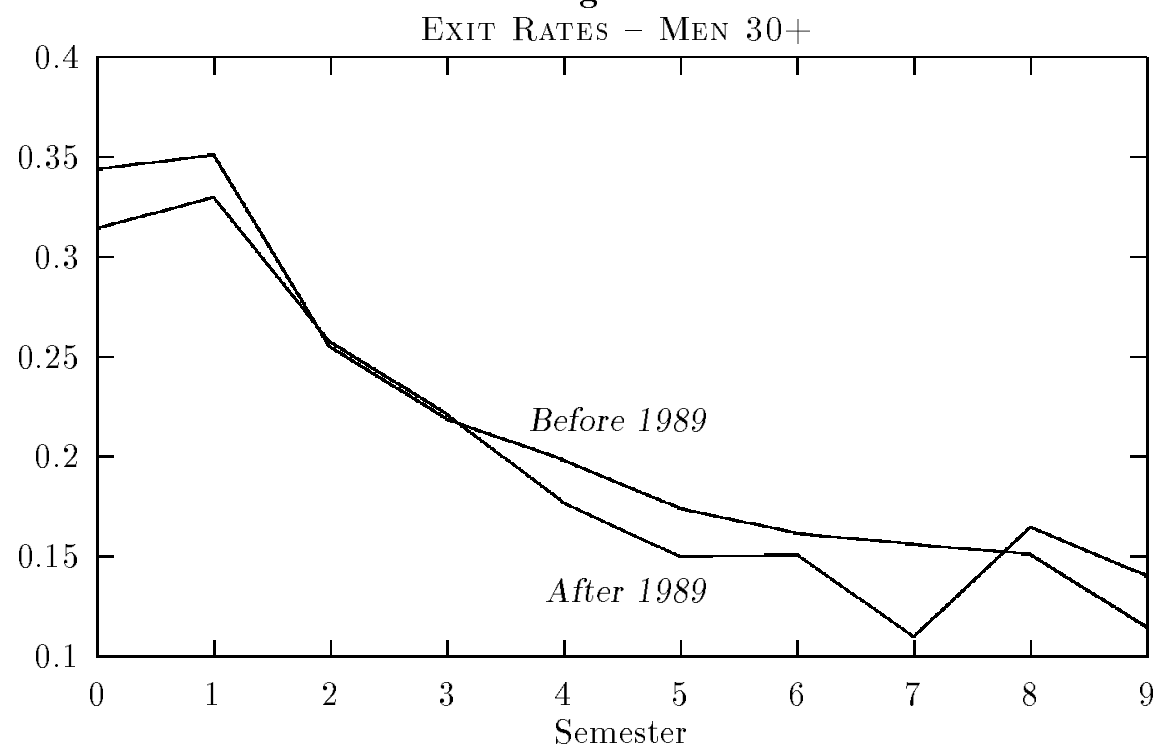




\section{Table $1^{\dagger}$}

\section{Sample Statistics}

\begin{tabular}{lccccccc}
\hline \hline \multicolumn{1}{c}{ Variable } & \multicolumn{3}{c}{ Women } & \multicolumn{4}{c}{ Men } \\
\multicolumn{1}{c}{ Age group: } & $\overbrace{18-24}^{c}$ & $25-29$ & $30-45$ & $\overbrace{18-24}$ & $25-29$ & $30-45$ \\
& 14.68 & 25.28 & 35.93 & 11.21 & 15.06 & 23.30 \\
Spell length $^{1}$ (months) & 0.09 & 0.16 & 0.19 & 0.09 & 0.14 & 0.19 \\
Censored $^{2}$ & 17319 & 5146 & 5350 & 26042 & 12469 & 17066
\end{tabular}

A. Variables that are constant over spell:

$\begin{array}{lcccccc}\text { Years of education } & 10.93 & 11.46 & 11.16 & 10.35 & 10.84 & 10.53 \\ & (2.19) & (3.04) & (3.49) & (2.16) & (2.82) & (3.39) \\ \text { Born in Canada } & 0.95 & 0.90 & 0.88 & 0.94 & 0.89 & 0.85 \\ & (0.21) & (0.28) & (0.31) & (0.22) & (0.31) & (0.34) \\ \text { City of Montreal } & 0.13 & 0.24 & 0.31 & 0.17 & 0.26 & 0.32\end{array}$

B. VARIABLES Wich VARY OVER SPELL:

\begin{tabular}{|c|c|c|c|c|c|c|}
\hline Age at start of spell & $\begin{array}{l}20.86 \\
(1.73)\end{array}$ & $\begin{array}{l}26.72 \\
(1.40)\end{array}$ & $\begin{array}{l}36.53 \\
(4.07)\end{array}$ & $\begin{array}{l}21.12 \\
(1.79)\end{array}$ & $\begin{array}{l}26.81 \\
(1.40)\end{array}$ & $\begin{array}{l}36.13 \\
(3.97)\end{array}$ \\
\hline Monthly welfare benefits ${ }^{3}$ & & & $\begin{array}{l}449.65 \\
(12.85)\end{array}$ & & $\begin{array}{l}.23 \\
.99)\end{array}$ & $\begin{array}{l}449.65 \\
(12.85)\end{array}$ \\
\hline Unemployment Rate ${ }^{4}$ & \multicolumn{6}{|c|}{$\begin{array}{c}8.63 \\
(2.46)\end{array}$} \\
\hline Minimum wage & \multicolumn{6}{|c|}{$\begin{array}{c}4.84 \\
(0.72)\end{array}$} \\
\hline U.I. Generosity & \multicolumn{6}{|c|}{$\begin{array}{c}3.67 \\
(0.88)\end{array}$} \\
\hline
\end{tabular}

\footnotetext{
$\dagger$ Figures in 1986 dollars.

${ }^{1}$ Computed from Kaplan-Meir exit rates.

${ }^{2}$ Censoring date is December 1993.

${ }^{3}$ Computed from program parameters for the sample period.

${ }^{4}$ Men 25-64 years of age.
} 
Table 2

Hasard Model Estimation - Women ${ }^{\dagger}$

\begin{tabular}{|c|c|c|c|c|c|c|}
\hline \multirow{2}{*}{ Variable } & \multicolumn{2}{|c|}{$18-24$} & \multicolumn{2}{|c|}{$25-29$} & \multicolumn{2}{|c|}{$30-45$} \\
\hline & \multicolumn{4}{|c|}{ Individual characteristics } & & \\
\hline Schooling & $0.1818^{*}$ & $(0.0053)$ & $0.1139^{*}$ & $(0.0062)$ & $0.0151^{*}$ & $(0.0050)$ \\
\hline Born in Canada & -0.0569 & $(0.0439)$ & $0.1261^{*}$ & $(0.0650)$ & 0.0903 & $(0.0569)$ \\
\hline \multirow[t]{2}{*}{ Age } & $-0.0214^{*}$ & $(0.0005)$ & $-0.0044^{*}$ & $(0.0010)$ & $-0.0058^{*}$ & $(0.0003)$ \\
\hline & \multicolumn{4}{|c|}{ Seasonnal Effects } & & \\
\hline April-June & $0.2218^{*}$ & $(0.0236)$ & 0.0574 & $(0.0462)$ & 0.0677 & 0.0458 \\
\hline July-Septembre & $0.4236^{*}$ & $(0.0220)$ & $0.1996^{*}$ & $(0.0437)$ & $0.1407^{*}$ & 0.0445 \\
\hline \multirow[t]{2}{*}{ Octobre-Decembre } & $0.1830^{*}$ & $(0.0245)$ & $-0.0805^{* *}$ & $(0.0481)$ & $0.0971^{*}$ & 0.0482 \\
\hline & \multicolumn{4}{|c|}{ Policy Variables } & & \\
\hline Welfare Benefits & $-0.0008^{*}$ & $(0.0003)$ & -0.0004 & $(0.0005)$ & -0.0015 & $(0.0021)$ \\
\hline Minimum Wage & $-0.1652^{*}$ & $(0.0291)$ & $0.6581^{*}$ & $(0.1410)$ & -0.0940 & $(0.1457)$ \\
\hline Unemployment Rate & $-0.0849^{*}$ & $(0.0094)$ & -0.0259 & $(0.0195)$ & 0.0107 & $(0.0172)$ \\
\hline U.I. Generosity & -0.0493 & $(0.0402)$ & -0.0232 & $(0.0766)$ & $-0.2616^{*}$ & $(0.1218)$ \\
\hline$\sigma$ & - & - & 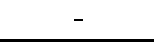 & - & - & - \\
\hline \multirow[b]{2}{*}{ Months } & \multicolumn{4}{|c|}{ AVERage Monthly Baseline Exit Rates } & \multirow[b]{2}{*}{$\begin{array}{c}\text { Hazard } \\
\text { rate }\end{array}$} & \multirow[b]{2}{*}{$\begin{array}{l}\text { Std. } \\
\text { error }\end{array}$} \\
\hline & $\begin{array}{l}\text { Hazard } \\
\text { rate }\end{array}$ & $\begin{array}{l}\text { Std. } \\
\text { error }\end{array}$ & $\begin{array}{l}\text { Hazard } \\
\text { rate }\end{array}$ & $\begin{array}{l}\text { Std. } \\
\text { error }\end{array}$ & & \\
\hline 1 & 0.0552 & $(0.0042)$ & 0.0597 & $(0.0100)$ & 0.0674 & $(0.0034)$ \\
\hline 2 & 0.0802 & $(0.0059)$ & 0.0726 & $(0.0118)$ & 0.0803 & $(0.0039)$ \\
\hline 3 & 0.0940 & $(0.0068)$ & 0.0765 & $(0.0128)$ & 0.0834 & $(0.0047)$ \\
\hline 4 & 0.0965 & $\left(0.00^{\prime}\right.$ & 0.0868 & $(0.0150)$ & 0.0782 & $(0.0054)$ \\
\hline 5 & 0.1001 & $(0.0073)$ & 0.0695 & $(0.0121)$ & 0.0806 & $(0.0063)$ \\
\hline 6 & 0.0988 & $(0.00$ & 0.0681 & $(0.0121)$ & 0.0804 & $(0.0074)$ \\
\hline 7 & 0.0969 & $(0.0073)$ & 0.0618 & $(0.0111)$ & 0.0725 & $(0.0076)$ \\
\hline 8 & 0.0937 & $(0.0071)$ & 0.0535 & $(0.0102)$ & 0.0743 & $(0.0086)$ \\
\hline 9 & 0.0936 & $(0.0073)$ & 0.0523 & $(0.0099)$ & 0.0676 & $(0.0086)$ \\
\hline 10 & 0.0941 & $(0.0074)$ & 0.0524 & $(0.0094)$ & 0.0675 & $(0.0093)$ \\
\hline 11 & 0.0986 & $(0.0078)$ & 0.0481 & $(0.0085)$ & 0.0681 & $(0.0101)$ \\
\hline 12 & 0.1077 & $(0.0085)$ & 0.0507 & $(0.0091)$ & 0.0741 & $(0.0117)$ \\
\hline 13 & 0.0982 & $(0.0081)$ & 0.0454 & $(0.0086)$ & 0.0597 & $(0.0108)$ \\
\hline 14 & 0.0902 & $(0.0078)$ & 0.0314 & $(0.0063)$ & 0.0701 & $(0.0131)$ \\
\hline $15-16$ & 0.0972 & $(0.0076)$ & 0.0330 & $(0.0054)$ & 0.0597 & $(0.0116)$ \\
\hline $17-1$ & 0.0924 & $(0.0075)$ & 0.0294 & $(0.0052)$ & 0.0544 & $(0.0117)$ \\
\hline $19-2$ & 0.0954 & $(0.0077)$ & 0.0253 & $(0.0042)$ & 0.0433 & $(0.0100)$ \\
\hline $22-2$ & 0.1045 & $(0.0083)$ & 0.0214 & $(0.0049)$ & 0.0572 & $(0.0145)$ \\
\hline $26-31$ & 0.1078 & $(0.0089)$ & 0.0179 & $(0.0052)$ & 0.0454 & $(0.0137)$ \\
\hline $32-39$ & .1344 & $(0.0116)$ & 0.0131 & $(0.0051)$ & 0.0433 & $(0.0156)$ \\
\hline Obsert & \multicolumn{2}{|c|}{17319} & \multicolumn{2}{|c|}{5146} & \multicolumn{2}{|c|}{5350} \\
\hline
\end{tabular}

$\dagger$ Standard errors in parentheses. The specification also includes 18 year dummies and 12 region dummies..

* Statistically significant at 5\%. ${ }^{* *}$ Statistically significant at $10 \%$. 


\section{Table 3}

Hasard Model Estimation - Men ${ }^{\dagger}$

\begin{tabular}{|c|c|c|c|c|c|c|}
\hline Variable & & & 25 & & 30 & 45 \\
\hline & & ividual $C$ & aracteristic & & & \\
\hline Schooling & $0.0976^{*}$ & $(0.0465)$ & $0.0048^{*}$ & $(0.0051)$ & 0.0041 & $(0.0028)$ \\
\hline Born in Canada & -0.0065 & $(0.0349)$ & $0.0774^{* *}$ & $(0.0439)$ & -0.0093 & $(0.0297)$ \\
\hline Age & $-0.0097^{*}$ & $(0.0003)$ & -0.0058 & $(0.0066)$ & $-0.0061^{*}$ & $(0.0002)$ \\
\hline & & Seasonn & Effects & & & \\
\hline April-June & $0.3500^{*}$ & $(0.0190)$ & $0.2098^{*}$ & $(0.0280)$ & $0.1508^{*}$ & $(0.0252)$ \\
\hline July-Septembre & $0.5230^{*}$ & $(0.0183)$ & $0.3542^{*}$ & $(0.0272)$ & $0.2901^{*}$ & $(0.0243)$ \\
\hline Octobre-Decembre & $0.2084^{*}$ & $(0.0203)$ & $-0.0543^{* *}$ & $(0.0301$ & $0.1296^{*}$ & $(0.0270)$ \\
\hline & & Policy & riables & & & \\
\hline Welfare Benefits & $-0.0009^{*}$ & $(0.0002)$ & $-0.0011^{*}$ & $(0.0003)$ & -0.0015 & $(0.0011)$ \\
\hline Minimum Wage & $-0.1123^{* *}$ & $(0.0597)$ & $0.3113^{*}$ & $(0.0918)$ & $0.1523^{*}$ & $(0.0796)$ \\
\hline Unemployment Rate & $-0.0603^{*}$ & $(0.0080)$ & $-0.0679^{*}$ & $(0.0123)$ & $-0.0707^{*}$ & $(0.0090)$ \\
\hline U.I. Generosity & $-0.1744^{*}$ & $(0.0358)$ & -0.0029 & $(0.5103)$ & 0.0318 & $(0.0597)$ \\
\hline $\bar{\sigma}$ & - & - & $0.1749^{*}$ & $\overline{(0.0437)}$ & - & - \\
\hline & $\overline{\text { AVERAGE } 1}$ & $\overline{\text { ONTHLY } 1}$ & ASELINE E & IT RATES & & \\
\hline Months & $\begin{array}{l}\text { Hazard } \\
\text { rate }\end{array}$ & $\begin{array}{l}\text { Std. } \\
\text { error }\end{array}$ & $\begin{array}{l}\text { Hazard } \\
\text { rate }\end{array}$ & $\begin{array}{l}\text { Std. } \\
\text { error }\end{array}$ & $\begin{array}{l}\text { Hazard } \\
\text { rate }\end{array}$ & $\begin{array}{l}\text { Std. } \\
\text { error }\end{array}$ \\
\hline 1 & 0.0712 & $\overline{(0.0043)}$ & 0.0831 & $\overline{(0.0088)}$ & 0.0612 & $\overline{(0.0018)}$ \\
\hline 2 & 0.1114 & $(0.0065)$ & 0.1089 & $(0.0119)$ & 0.0744 & $(0.0022)$ \\
\hline 3 & 0.1292 & $(0.0074)$ & 0.1415 & $(0.0165)$ & 0.0831 & $(0.0026)$ \\
\hline 4 & 0.1538 & $(0.0087)$ & 0.1428 & $(0.0183)$ & 0.0840 & $(0.0030)$ \\
\hline 5 & 0.1347 & $(0.0079)$ & 0.1493 & $(0.0203)$ & 0.0790 & $(0.0034)$ \\
\hline 6 & 0.1375 & $(0.0081)$ & 0.1287 & $(0.0187)$ & 0.0798 & $(0.0039)$ \\
\hline 7 & 0.1336 & $(0.0080)$ & 0.1175 & $(0.0176)$ & 0.0751 & $(0.0041)$ \\
\hline 8 & 0.1322 & $(0.0081)$ & 0.1334 & $(0.0199)$ & 0.0719 & $(0.0044)$ \\
\hline 9 & 0.1293 & $(0.0080)$ & 0.1262 & $(0.0187)$ & 0.0738 & $(0.0049)$ \\
\hline 10 & 0.1346 & $(0.0085)$ & 0.1168 & $(0.0169)$ & 0.0682 & $(0.0050)$ \\
\hline 11 & 0.1247 & $(0.0081)$ & 0.1028 & $(0.0154)$ & 0.0699 & $(0.0055)$ \\
\hline 12 & 0.1251 & $(0.0084)$ & 0.1252 & $(0.0190)$ & 0.0699 & $(0.0060)$ \\
\hline 13 & 0.1329 & $(0.0090)$ & 0.1268 & $(0.0208)$ & 0.0726 & $(0.0068)$ \\
\hline 14 & 0.1067 & $(0.0078)$ & 0.0980 & $(0.0177)$ & 0.0562 & $(0.0060)$ \\
\hline $15-16$ & 0.1074 & $(0.0073)$ & 0.0744 & $(0.0134)$ & 0.0554 & $(0.0059)$ \\
\hline $17-18$ & 0.1095 & $(0.0077)$ & 0.0784 & $(0.0153)$ & 0.0544 & $(0.0066)$ \\
\hline $19-21$ & 0.1055 & $(0.0075)$ & 0.0814 & $(0.0152)$ & 0.0580 & $(0.0076)$ \\
\hline $22-25$ & 0.1108 & $(0.0077)$ & 0.0716 & $(0.0156)$ & 0.0532 & $(0.0078)$ \\
\hline $26-31$ & 0.0985 & $(0.0075)$ & 0.0599 & $(0.0144)$ & 0.0435 & $(0.0077)$ \\
\hline $32-39$ & 0.1052 & $(0.0086)$ & 0.0568 & $(0.0174)$ & 0.0424 & $(0.0089)$ \\
\hline Observations & & & 12 & & & \\
\hline
\end{tabular}


Table 4

Elasticities of Expected Duration ${ }^{\dagger}$

\begin{tabular}{c|cccc}
\hline & \multicolumn{4}{|c}{ VARIABLE } \\
\cline { 2 - 5 } & Benefits & $\begin{array}{c}\text { Minimum } \\
\text { wage }\end{array}$ & $\begin{array}{c}\text { Unemp. } \\
\text { rate }\end{array}$ & Schooling \\
\hline Women & & & & \\
$18-24$ & $0.1910^{*}$ & $0.7866^{*}$ & $1.0349^{*}$ & $-2.0945^{*}$ \\
& $(0.0732)$ & $(0.3494)$ & $(0.1163)$ & $(0.0589)$ \\
$25-29$ & 0.1309 & $-3.2887^{*}$ & 0.3374 & $-1.4610^{*}$ \\
& $(0.1469)$ & $(0.7094)$ & $(0.2562)$ & $(0.0819)$ \\
$30-45$ & 0.7661 & 0.4533 & -0.1372 & $-0.1857^{*}$ \\
& $(1.0372)$ & $(0.7006)$ & $(0.2210)$ & $(0.0637)$ \\
\cline { 2 - 5 } Men & & & & \\
$18-24$ & $0.2281^{*}$ & $0.5501^{* *}$ & $0.7643^{*}$ & $-1.0964^{*}$ \\
& $(0.0622)$ & $(0.2913)$ & $(0.1019)$ & $(0.0445)$ \\
$25-29$ & $0.3075^{*}$ & $-1.5661^{*}$ & $0.8635^{*}$ & $-0.5603^{*}$ \\
& $(0.1056)$ & $(0.4443)$ & $(0.1611)$ & $(0.0528)$ \\
$30-45$ & 0.7765 & -0.7647 & $0.9485^{*}$ & -0.0495 \\
& $(0.5981)$ & $(0.3998)$ & $(0.1220)$ & $(0.0345)$ \\
\hline
\end{tabular}

$\bar{\dagger}$ The elasticities are evaluated at the mean of the explanatory variables.

* Statistically significant at $5 \%$.

** Statistically significant at $10 \%$. 


\section{Liste des publications au CIRANO .}

\section{Cahiers CIRANO / CIRANO Papers (ISSN 1198-8169)}

96c-1 Peut-on créer des emplois en réglementant le temps de travail ? / par Robert Lacroix

95c-2 Anomalies de marché et sélection des titres au Canada / par Richard Guay, JeanFrançois L'Her et Jean-Marc Suret

95c-1 La réglementation incitative / par Marcel Boyer

94c-3 L'importance relative des gouvernements : causes, conséquences et organisations alternative / par Claude Montmarquette

94c-2 Commercial Bankruptcy and Financial Reorganization in Canada / par Jocelyn Martel

94c-1 Faire ou faire faire : La perspective de l'économie des organisations / par Michel Patry

Série Scientifique / Scientific Series (ISSN 1198-8177)

97s-26 Industrie aérospatiale nord-américaine et performance des sous-traitants : Écarts entre le Canada et les États-Unis / Mario Bourgault

97s-25 Welfare Benefits, Minimum Wage Rate and the Duration of Welfare Spells: Evidence from a Natural Experiment in Canada / Bernard Fortin et Guy Lacroix

97s-24 Incentive Effects of Public Insurance Programs on the Occurence and the Composition of Workplace Injuries / Denis Bolduc, Bernard Fortin, France Labrecque et Paul Lanoie

97s-23 Contrat dynamique de partage de risque avec contraintes d'engagement et épargne / Karine Gobert et Michel Poitevin

97s-22 Comparing Open-Loop with Markov Equilibria in a Class of Differential Games / Ngo Van Long, Koji Shimomura et Harataka Takahashi

97s-21 Efficiency Inducing Taxation for Polluting Oligopolists / Hassan Benchekroun et Ngo Van Long

97s-20 Tests of Conditional Asset Pricing Models in the Brazilian Stock Market / Marco Bonomo et René Garcia

97s-19 Nonparametric Methods and Option Pricing / Eric Ghysels, Valentin Patilea, Éric Renault et Olivier Torrès

97s-18 Availability and Accuracy of Accounting and Financial Data in Emerging Markets: The Case of Malaysia / Jean-Marc Suret, Cameron Morrill et Janet Morrill

97s-17 L'évolution des structures financières des grandes entreprises canadiennes / Jean-Marc Suret et Jean-François L'Her

97s-16 Le régime d'épargne-actions du Québec : Vue d'ensemble et évaluation / Jean-Marc Suret et Élise Cormier

\footnotetext{
* Vous pouvez consulter la liste complète des publications du CIRANO et les publications elles-mêmes sur notre site World Wide Web à l'adresse suivante :

http://www.cirano.umontreal.ca/publication/page1.html
} 